\title{
Thematic Article \\ What controls the lateral variation of large earthquake occurrence along the Japan Trench?
}

\author{
Yuichiro Tanioka ${ }^{1 *}$, Larry RufF ${ }^{1}$ and Kenji Satake ${ }^{2}$ \\ ${ }^{1}$ Department of Geological Sciences, University of Michigan, Ann Arbor, MI 48109-1063, USA, ${ }^{2}$ Seismotectonics \\ Section, Geological Survey of Japan, Tsukuba 305, Japan
}

\begin{abstract}
The lateral (along trench axis) variation in the mode of large earthquake occurrence near the northern Japan Trench is explained by the variation in surface roughness of the subducting plate. The surface roughness of the ocean bottom near the trench is well correlated with the large-earthquake occurrence. The region where the ocean bottom is smooth is correlated with 'typical' large underthrust earthquakes (e.g. the 1968 Tokachi-oki event) in the deeper part of the seismogenic plate interface, and there are no earthquakes in the shallow part (aseismic zone). The region where the ocean bottom is rough (well-developed horst and graben structure) is correlated with large normal faulting earthquakes (e.g. the 1933 Sanriku event) in the outer-rise region, and large tsunami earthquakes (e.g. the 1896 Sanriku event) in the shallow region of the plate interface zone. In the smooth surface region, the coherent metamorphosed sediments form a homogeneous, large and strong contact zone between the plates. The rupture of this large strong contact causes great underthrust earthquakes. In the rough surface region, large outer-rise earthquakes enhance the well-developed horst and grabens. As these structure are subducted with sediments in the graben part, the horsts create enough contact with the overriding block to cause an earthquake in the shallow part of the interface zone, and this earthquake is likely to be a tsunami earthquake. When the horst and graben structure is further subducted, many small strong contacts between the plates are formed, and they can cause only small underthrust earthquakes.
\end{abstract}

Key words: earthquake occurrence, Japan Trench, subduction zone.

\section{INTRODUCTION}

The Pacific Plate subducts beneath the east coast of northern Japan along the Japan Trench. Many large earthquakes, including many underthrusting earthquakes, have occurred in this subduction zone. Figure 1 shows the most recent sequence of large earthquakes along the Japan Trench and the southern end of the Kurile Trench. The southern end of the Kurile Arc was ruptured by the 1952 Tokachi-oki earthquake $\left(M_{w} 8.2\right)$. The northernmost part of the Japan Trench (A in Fig. 1) was ruptured by the 1968 Tokachi-oki earthquake $\left(M_{w}\right.$ 8.2). Then, the 1994 Sanriku earthquake $\left(M_{w} 7.7\right)$ ruptured the southern part of the 1968 Tokachi-oki

*Present address: Seismology and Volcanology Department, MeteoroIogical Research Institute, Tsukuba, Ibaraki 305, Japan. Email: <ytanioka@mri-jma.go.jp>

Accepted for publication November 1996. source region where the slip during the 1968 event was relatively small (Tanioka et al. 1996). The typical recurrence interval of great earthquakes in this region is $\sim 80-100$ years as determined from the study of historical earthquakes (Utsu 1974). The central part of the Japan Arc (C in Fig. 1) has been also recently ruptured by large earthquakes. The most recent events occurred in 1897 and 1978. The 1897 Sanriku earthquake $\left(M_{w} 7.8\right)$ ruptured the shallower part of the seismic coupling zone (Aida 1977), and the 1978 Miyagi-oki earthquake $\left(\mathrm{M}_{\mathrm{w}}\right.$ 7.6) ruptured the down-dip edge of the seismic coupling zone (Seno et al. 1980). The recurrence interval for the 1978 Miyagi-oki-type events is $~ 40$ years (Kawakatsu \& Seno 1983).

In addition to these typical underthrust earthquakes, some unusual earthquakes have occurred 


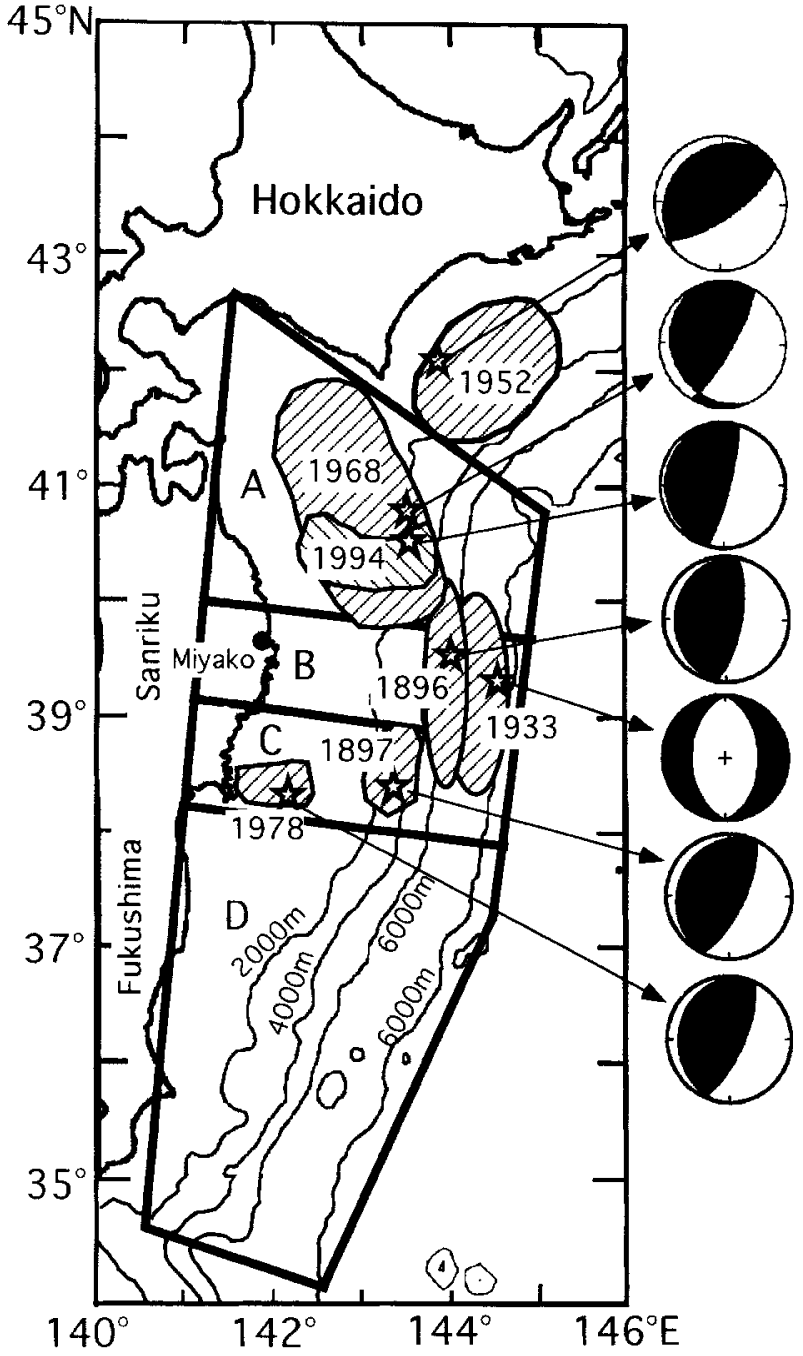

Fig. 1 Recent large earthquakes in the Japan Trench region. Hatched ellipsoids are source areas of the large earthquakes. Stars represent the epicentres. The focal mechanisms are shown to the right for the 1952 Tokachi-oki (Kasahara 1975), 1968 Tokachi-oki (Schwartz \& Ruff 1987), 1994 Kurile (Tanioka et al. 1996), 1896 Sanriku (Tanioka \& Salake 1996), 1933 Sanriku (Kanamori 1971), 1897 Sanriku (Aida 1977), and 1978 Miyagi-oki (Seno 1980) earthquakes. Thick lines divide the different areas $(A, B, C$ and $D)$.

in this subduction zone (Fig. 1). To the south of the source region of the 1994 Sanriku earthquake and near the Japan Trench (B in Fig. 1), the 1933 Sanriku-oki earthquake $\left(\mathrm{M}_{\mathrm{w}}=8.6\right)$ was a tensional outer-rise event that may have broken the entire lithosphere (Kanamori 1971). The 1896 Sanriku earthquake was a tsunami earthquake; it caused a great disaster along the Sanriku coast. A tsunami earthquake is defined as an earthquake that excites much larger tsunamis than expected from its seismic waves (Kanamori 1972). The discrepancy between a 'tsunami earthquake' and a 'typical earthquake' can be quantified in terms of the difference between the surface wave magnitude $\left(\mathrm{M}_{\mathrm{s}}\right)$ and the tsunami magnitude $\left(\mathrm{M}_{\mathrm{t}}\right)$. In the case of the 1896 Sanriku tsunami earthquake, the surface wave magnitude $\left(\mathrm{M}_{\mathrm{s}}\right)$ was 7.2 while the tsunami magnitude $\left(\mathbb{M}_{t}\right)$ was 8.6 , which is larger by more than an order of magnitude (Abe 1979, 1994). Kanamori (1972) suggested that the large discrepancy between seismic and tsunami waves is explained by a slow rupture process. Okal (1988) showed that an earthquake source in shallow sedimentary layers excites much larger tsunamis than for a source in solid rock. Recently, Tanioka \& Satake (1996) analysed the tsunami waveforms and a travel time from the 1896 Sanriku earthquake (Fig. 1). They found that the rupture area of the 1896 earthquake was very close to the trench and located west of the source region of the 1933 outerrise event.

As we have demonstrated, a lateral (alongstrike) variation in the mode of large earthquake occurrence exists along the Japan Arc. Kawakatsu and Seno (1983) indicated that in regions $\mathrm{A}$ and $\mathrm{C}$ (i.e. north of $40^{\circ} \mathrm{N}$ and $38^{\circ} \mathrm{N}-39^{\circ} \mathrm{N}$ ), great underthrust earthquakes have occurred regularly. On the other hand, the region $\mathrm{B}$ between $39^{\circ} \mathrm{N}$ and $40^{\circ} \mathrm{N}$ has not experienced typical great underthrust-type earthquakes for at least the past 200 years, and has had only unusual, large outer-rise and tsunami earthquakes as mentioned above. Kawakatsu and Seno (1983) also studied earthquakes with smaller magnitudes and suggested that the plate interface in region $B$ also lacks smaller underthrust earthquakes. To the south of $38^{\circ} \mathrm{N}$, there have been no large underthrust, outerrise, or tsunami earthquakes. Thus, we exclude the region south of $38^{\circ} \mathrm{N}$ (D in Fig. 1) from the present study and concentrate on the northern part of the Japan Are (A, B and C in Fig. 1).

The key question is: what controls this variation in the mode of large-earthquake occurrence along the northern Japan Trench? In order to answer this question, we incorporate different types of geophysical information. Fortunately, many geophysical observations such as microseismicity observations, detailed crustal structure, and detailed bathymetry, are available for the Japan Trench. We first describe the various observations in this region, then present our model to connect those observations to the occurrence of large earthquakes.

\section{GEOPHYSICAL OBSERVATIONS}

\section{MICROSEISMICITY}

Microseismicity along the Japan Trench has been studied using the ocean bottom seismometer 
(OBS) arrays which have been extensively deployed in this region. Hirata et al. (1989) studied microearthquake activity in the southernmost Kurile Trench and the northernmost Japan Trench area. They conclude that an aseismic zone exists near the trench axis. Nishizawa et al. (1992) studied microearthquake activity in two regions, off Sanriku in the north (A, B and C in Fig. 1) and off Fukushima in the south (D in Fig. 1). They found that the aseismic zone off Fukushima has a width of more than $100 \mathrm{~km}$ with the eastern edge at the trench, and the aseismic zone off Sanriku has a width of $\sim 50 \mathrm{~km}$.

\section{SLIP DISTRIBUTION OF TWO LARGE EARTHQUAKES}

\section{The 1994 Sanriku earthquake}

Tanioka et al. (1996) determined the slip distribution of this earthquake using the tsunami waveforms recorded at eight tide gauge stations (four in Hokkaido and four in Honshu), and horizontal coseismic displacements observed at 10 GPS stations (four in Hokkaido and six in Honshu). The good coverage of the stations (both tide gauges and GPS stations) allowed the detailed slip distribution to be determined. Tanioka et al. (1996) found that essentially no slip occurred near the trench ( $<\sim 30 \mathrm{~km}$ from the trench), but that the slip was concentrated at the down-dip edge of the seismic coupling zone. This means that the 1994 Sanriku earthquake did not rupture the shallow aseismic zone determined by the microseismicity study.

\section{The 1896 Sanriku tsunami earthquake}

Tanioka and Satake (1996) estimated the fault strike and width of this earthquake by numerically computing synthetic tsunami waveforms and comparing them with the observed tsunami waveforms from three tide gauge stations, one in Hokkaido and two in Honshu. They found that the fault strike is parallel to the trench axis and the fault width is $\sim 50 \mathrm{~km}$. They also determined the fault location (distance from the trench axis) by comparing the observed tsunami travel time at Miyako (Fig. 1) with the computed one. The travel time at Miyako is sensitive to the fault location because Miyako is located in a direction perpendicular to the fault strike or the trench axis. They found that the fault is located very close to the trench, and the eastern edge of the fault reaches the trench axis. Thus, the 1896 Sanriku earthquake occurred in the aseismic zone determined from the microseismicity study.

\section{CRUSTAL STRUCTURE AND BATHYMETRY}

Marine seismic surveys (e.g. seismic reflection, two-ship refraction and OBS refraction surveys) accurately define the geometry and structure of the subducting plate near the trench. Suyehiro and Nishizawa (1994) analysed the multichannel seismic (MCS) and OBS data near the northern Japan Trench (A, B and C in Fig. 1). They found that in the overriding block, hard material with a $\mathrm{P}$ wave velocity of $\sim 6 \mathrm{~km} / \mathrm{s}$ can be found as near as $35 \mathrm{~km}$ from the trench axis. They suggested that the present accretionary prism in this region must be very small, and extends only $35 \mathrm{~km}$ landward from the trench.

The study of von Huene et al. (1994) revealed the detailed structure near the northern Japan Trench region (A in Fig. 1) using pre-stack depthmigrated seismic data. They successfully imaged the subducted sediments along the subducting plate and found the sediment layer at a $12 \mathrm{~km}$ depth, which corresponds to $45 \mathrm{~km}$ landward from the trench axis. The thickness of the sediment layer increases with depth and at the $12 \mathrm{~km}$ depth, the sediment layer is $1-1.5 \mathrm{~km}$ thick. The layer between the overriding block and the subducting oceanic plate is the plate interface zone. The convergence of the plates is mostly accommodated in this plate interface zone, although some portion of the plate convergence is accommodated in the accretionary prism. Cloos and Sherive (1988) interpreted the plate interface zone as a subduction channel in which the subducted sediment deforms as a viscous fluid as it is dragged down by the subducting plate. They also classified the Northeast Japan region as a Type A margin (Cloos $\&$ Sherive 1988), in which all incoming sediment is subducted.

Honza (1980) showed detailed bathymetry profiles in the Japan Trench area that were obtained by a cruise for marine geological and geophysical investigations in the Japan and Kurile Trenches. Figure 2 shows the 18 bathymetry profiles from Honza (1980) and also two (ORI-3 and -4) from Nasu et al. (1980). The profiles in the central part (10-14 in Fig. 2) show that the ocean bottom near the trench axis is rougher than those in the northern and southern profiles (3-9 and 15-20 in Fig. 2).

\section{MODEL FOR ROUGHNESS AND EARTHQUAKE OCCURRENCE}

From the bathymetry profile data in Fig. 2 (Honza 1980; Nasu et al. 1980), we categorize the subducting lithosphere in the central part (profiles 10-14) 


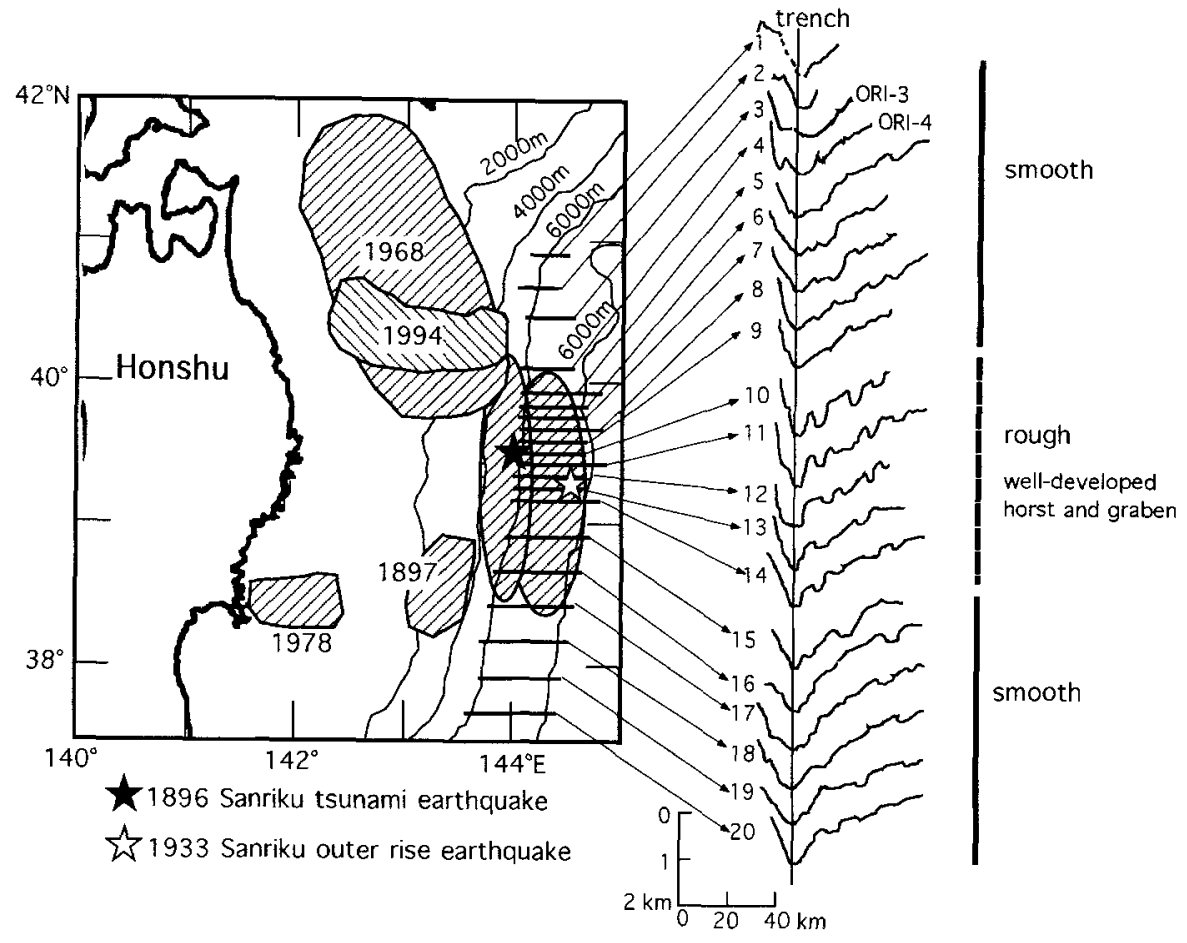

Fig. 2 (right) Bathymetry profiles along the Japan Trench and (left) the source regions of the recent large earthquakes. Two profiles, ORI-3 and ORI-4, are from Nasu ot al. (1980) and the other 18 profiles are from Honza (1980). The solid star is at the epicentre of the 1896 Sanriku tsunami earthquake. The open star is at the epicentre of the 1933 Sanriku outer-rise earthquake. (a)

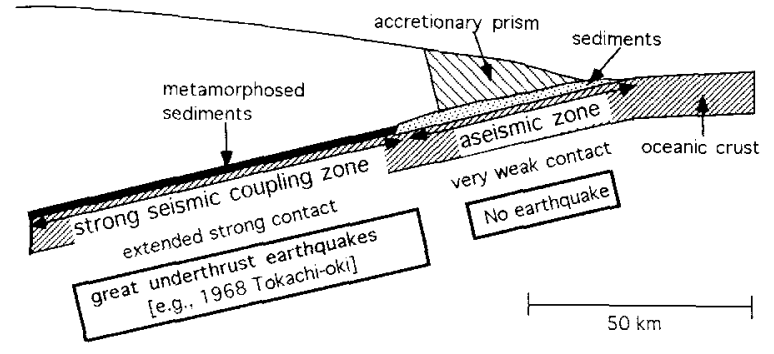

(b)

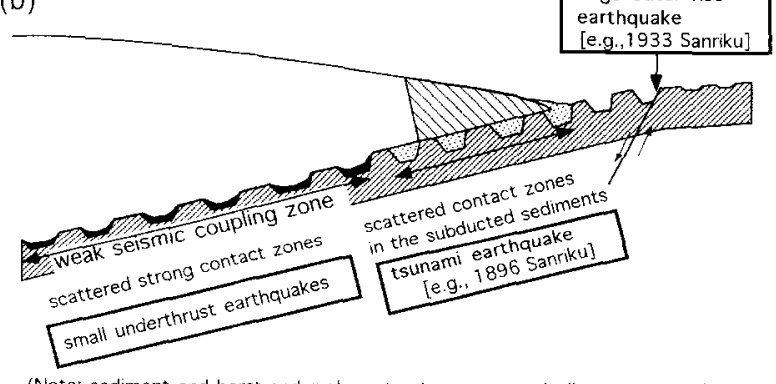

(Note: sediment and horst and graben structures are vertically exaggerated)

Fig. 3 Schematic illustration of our model to explain the reiationship between roughness of the plate interface and earthquake occurrence. (a) Smooth surface; (b) rough surface. Sediments, metamorphosed sediments, and horst and graben structures are vertically exaggerated. The plate interface zone includes the sediments above the subducting plate.

of Fig. 2 as 'rough' (well-developed horst and graben structure), and the other parts (profiles $3-9,15-20$ ) as 'smooth'. We then immediately notice the relationship between the ocean bottom roughness and the mode of occurrence of large earthquakes. The source regions of the 1933 Sanriku outer-rise earthquake and the 1896 Sanriku tsunami earthquake are well correlated with the 'rough' region. The source regions of the large underthrust earthquakes (the 1968 Tokachioki, 1897 and 1994 Sanriku and 1978 Miyagi-oki earthquakes) are well correlated with the 'smooth' region. The next question is how we can explain these relationships.

\section{THE SMOOTH SURFACE REGION}

First we discuss the aseismic zone near the trench in Fig. 3a. Microseismicity observations (Hirata et al. 1989; Nishizawa et al. 1992) show that the aseismic plate interface zone exists near the Japan Trench. The crustal structure studies from the marine seismic surveys show that the accretionary prism is very small, limited to the distance of 35 $\mathrm{km}$ from the trench axis (Suyehiro \& Nishizawa 1994). Also, a subducted sediment layer exists between the overriding block and the subducting plate, down to at least a $12 \mathrm{~km}$ depth, that is, a distance of $45 \mathrm{~km}$ from the trench axis (von Huene et al. 1994). Tanioka et al. (1996) showed that the 1994 Sanriku earthquake did not rupture the aseismic zone. These observations are basically consistent with the conclusions of Byrne et al. (1988), who suggested that the primary cause for the aseismic zone is the stable slip (velocity strengthening) properties of the unconsolidated or semiconsolidated sediments in that zone. 
Next we discuss the deeper seismogenic part of the plate interface zone in Fig. 3a. When sediments are subducted deeper along the subducting plate, they lose water, metamorphose and begin to exhibit stick-slip behaviour (Hyndman et al. 1997). This makes the plate interface 'seismically coupled'. Because the subducting plate surface is smooth, the seismic coupling zone is homogeneous, and the large strong contact can be created (Fig. 3a; Ruff 1989). When this large strong contact ruptures, a great underthrust earthquake occurs (e.g. the 1968 Tokachi-oki earthquake).

\section{THE ROUGH SURFACE REGION}

First we discuss the outer-rise region in Fig. 3b. One important observation is that the 1933 Sanriku outer-rise earthquake occurred in this region with normal faulting, which may have broken the entire lithosphere (Kanamori 1971). Bathymetric evidence for outer-rise earthquakes was also obtained by an ocean floor survey in this region using a research submersible boat (Ogawa 1994). Such earthquakes should enhance the horst and graben structure and produce the rough surface in the ocean bottom. This may explain why we have a rough surface in the central part (profiles 10-14 in Fig. 2) of the Japan Trench area, and implies that outer-rise earthquakes may have been concentrated in the 1933 source region over a geological time scale.

Next we discuss the shallower part of the plate interface zone in Fig. 3b. Another important observation is that the 1896 Sanriku tsunami earthquake occurred in this region. This earthquake ruptured the plate interface zone very close to the trench where large amounts of sediments exist, and no earthquake is expected to occur (Tanioka \& Satake 1996). We now describe our model that solves this paradox. When the well-developed horst and graben structure (rough region) is subducted along the trench, sediments fill in the graben 'buckets' (Fig. 3b; Hilde 1983). When this horst and graben structure is further subducted, the horst region may directly contact the overriding block. If this contact is strong enough to cause an earthquake, the earthquake is likely to be a tsunami earthquake because the large amounts of surrounding sediments cause a slow rupture and also enhance the tsunami excitation as suggested by Okal (1988).

Finally, we discuss the seismic coupling zone in Fig. 3b. Like the smooth surface case, when sediments are subducted into the deeper part of the plate interface, they lose water, metamorphose and begin to exhibit stick-slip behaviour. However, the rough (heterogeneous) surface of the plate interface creates many small strong contacts along the seismogenic interface. These small contacts should not cause a large underthrust earthquake, but may cause small underthrust events (Ruff 1989). However, Kawakatsu and Seno (1983) show no evidence for either large- or moderatesize underthrust earthquakes in this region, so further modification of our model for smaller earthquakes may be necessary.

\section{CONCLUSION}

The lateral variation in the mode of large earthquake occurrence in the plate interface along the northern Japan Trench is controlled by the surface roughness of the subducting plate, which depends on the surface roughness of the ocean bottom near the trench. The rough surface of the ocean bottom might be created by large outer-rise earthquakes (e.g. the 1933 Sanriku earthquake). Our interpretation is summarized as follows.

\section{SMOOTH SURFACE REGION}

No earthquakes occur in the shallow part of the interface zone because of the large amounts of subducted sediments. Great underthrust earthquakes occur in the seismic coupling zone because coherent metamorphosed sediments form large homogeneous and strong contacts between the plates (e.g. the 1968 Tokachi-oki earthquake).

\section{ROUGH SURFACE REGION}

Tsunami earthquakes occur in the shallow part of the interface zone (e.g. the 1896 Sanriku earthquake). The rough surface creates enough contact with the overriding block to cause an earthquake. The surrounding sediments cause a slow rupture and enhance tsunami excitation. Many small underthrust earthquakes occur in the seismic coupling zone because the rough (heterogeneous) surface forms many small strong contacts between the plates.

In the present study we analysed only the Japan Trench area where detailed geophysical observations are available. Detailed geophysical observations at other subduction zones are needed in order to determine whether our model is universal. 


\section{ACKNOWLEDGEMENTS}

We thank R. von Huene for discussion at the International Lithosphere Program workshop. The discussion with R. Nolen-Hoeksema and J. Johnson was beneficial. We also thank T. Seno and M. Cloos for critical reviews. This work was supported by NSF (EAR 9405767).

\section{REFERENCES}

ABE K. 1979. Size of great earthquakes of 1873-1974 inferred from tsunami data. Journal of Geophysical Research 84, 1561-68.

ABE K. 1994. Instrumental magnitudes of historical earthquakes, 1892-1898. Bulletin of the Seismological Society of America 84, 415-25.

AIDA I. 1977. Simulation of large tsunamis occurring in the past off the coast of the Sanriku district. Bulletin of the Earthquake Research Institute of the University of Tokyo 52, 71-101.

Byrne D. E., Davies D. M. \& Sykes L. R. 1988. Loci and maximum size of thrust earthquakes and the mechanics of the shallow region of subduction zones. Tectonics 7, 833-57.

Cloos M. \& Sherive R. L. 1988. Subduction-channel of prism accretion, melange formation, sediment subduction, and subduction erosion at convergent plate margins: 2. Implications and discussion. Pure and Applied Geophysics 128, 501-45.

HILDE T. W. C. 1983. Sediment subduction vs accretion around the Pacific. Tectonophysics 99, 381-97.

Hirata N., Kanazawa T., Suyehiro K., Iwasaki T. \& Shimamura H. 1989. Observation of microseismicity in the southern Kuril trench area by arrays of ocean bottom seismometers. Geophysical Journal International 98, 55-68.

HonzA E. 1980. Pre-sites survey of the Japan trench transect. Initial Reports of the Deep Sea Drilling Project 56/51, 449-58.

Hyndman R. D., Yamano M. \& Oleskevich D. A. 1997. The seismogenic zone of subduction thrust faults. The Island Arc 6, 244-260.

Kanamori H. 1971. Seismological evidence for a lithospheric normal faulting: The Sanriku earthquake of 1933. Physics of Earth and Planetary Interiors 4, 289-300.

KANAMORI H. 1972. Mechanism of tsunami earthquakes. Physics of Earth and Planetary Interiors 6, 246-59.

Kasahara M. 1975. A fault model of the Tokachi-oki earthquake of 1952 (in Japanese). Program and Abstract of Seismological Society ofJapan 2, 90. Seismological Society of Japan, Tokyo.
Kawakatsu H. \& Seno T. 1983. Triple seismic zone and the regional variation of seismicity along the northern Honshu arc. Journal of Geophysical Research 88, 4215-30.

Nasu N., Von Huene R., Ishiwada Y., Langseth T., BRUNS T. \& HoNZA E. 1980. Interpretation of multichannel seismic reflection data, Legs 56 and 57 , Japan trench transect. Initial Reports of the Deep Sea Drilling Project 56/51, 489-504.

Nishizawa A., Kanazawa T., IWasaki T., Shimamura H. \& Hirata N. 1992. Spatial distribution of earthquakes associated with the Pacific Plate subduction off northeastern Japan revealed by the ocean bottom and land observation. Physics of Earth and Planetary Interiors 75, 165-73.

OGAWA Y. 1994. Characteristics and origin of the cracks observed by research submersible 'Shinkai 6500 ' in the oceanward slope of the northern Japan Trench. Journal of Geography, Tokyo Geographical Society 103, 706-18 (in Japanese).

OKaL E. A. 1988. Seismic parameters controlling far-field tsunami amplitudes: A review. Natural Hazards 1, 67-96.

RUFF L. J. 1989. Do trench sediments affect great earthquake occurrence in subduction zones? Pure and Applied Geophysics 129, 263-82.

Seno T., Shimazaki K., Somerville P., Sudo K. \& EGUCHI T. 1980. Rupture process of the Miyagi-oki, Japan, earthquake of June 12, 1978. Physics of Earth and Planetary Interiors 23, 39-61.

SCHWARTZ S. Y. \& RuFF L. J. 1987. Asperity distribution and earthquake occurrence in the southern Kurile island arc. Physics of Earth and Planetary Interiors 49, 54-77.

SuYehiro K. \& Nishizawa A. 1994. Crustal structure and seismicity beneath the forearc off northeastern Japan. Journal of Geophysical Research 99, 22331-47.

Tanioka Y., Ruff L. \& Satake K. 1996. The Sanrikuoki, Japan, earthquake of December 28, 1994 ( $\mathrm{Mw}$ 7.7): Rupture of an asperity unbroken in a previous earthquake. Geophysical Research Letters 23, $1465-8$.

TANiokA Y. \& Satake K. 1996. Fault parameter of the 1896 Sanriku tsunami earthquake. Geophysical Research Letters 23, 1549-52.

UTSU T. 1974. Space-time pattern of large earthquakes occurring off the Pacific coast of the Japanese Island. Journal of Physics of the Earth 22, 325-42.

Von Huene R., Klaeschen D., Cropp B. \& Miller J. 1994. Tectonic structure across the accretionary and erosional parts of the Japan Trench margin. Journal of Geophysical Research 99, 22349-61. 